\title{
Hızla Yapılaşan Trabzon Kenti İçin Yeşil Odaklı Planlama Örneği: KTÜ Kanuni Kampüsü
}

\author{
Elif ÖZTÜRK ${ }^{1}$, Derya ELMALI ŞEN ${ }^{*}$ \\ ${ }^{1}$ KaradenizTeknikÜniversitesi, Mimarlık Fakültesi, Mimarlık Bölümü,61080, TRABZON
}

\section{Öz}

Yaşadığımız çağın en önemli sorunlarından biri küresel ısınma ve iklim değişikliği sorunudur. Hızla yapılaşan kentler, 1Sı adaları oluşturarak küresel 1sınma ve iklim değişikliğinin etkisinin artmasına sebep olmaktadır. Kentlerde doğal çevrenin desteklenmesi ve yeşil dokunun artırılması, 1sı adası etkisinin giderilmesinde en önemli araçlardan biridir. Çalışmada, Türkiye'nin hızla yapılaşan kentlerinden biri olan Trabzon kentinde bu soruna nasıl çözüm üretilebileceğine dair bir araştırma yapmak hedeflenmiştir. Türkiye'nin en yeşil şehirlerinden biri olmasına karşın Trabzon kent merkezinin yeşil dokusu azdır. Bu durum tersine çevrilip yeşil odaklı bir tasarımla kent gelişebilir mi sorusuna yanıt olarak Karadeniz Teknik Üniversitesi Kanuni Kampüsü incelenmiştir. İncelemeler sonucunda şehrin gelişmesi ile kent merkezinde kalan KTÜ Kanuni Kampüsü'nün temel yerleşim kararları bakımından kentin coğrafi yapısı, topografyası ve iklimi ile son derece uyumlu tasarlandığı ve yeşil odaklı tasarıma iyi bir örnek teşkil ettiği görülmüştür.

Anahtar Kelimeler: Isı Adası, Yeşil Odaklı Planlama, Trabzon Kenti, KTÜ Kanuni Kampüsü

\section{Green-Oriented Planning Example for the Rapidly Building City of Trabzon: KTU Kanuni Campus}

\begin{abstract}
One of the most important problems of our era is global warming and climate change. Rapidly building cities create heat islands, causing an increase in the impact of global warming and climate change. Supporting the natural environment and increasing the green texture in the cities is one of the most important tools in preventing the heat island effect. This study aims to research how to solve this problem in the city of Trabzon which is one of Turkey's rapidly building cities. Although Trabzon is one of the greenest cities in Turkey, there is lack of green space in downtown. Karadeniz Technical University Kanuni Campus was examined in order to find the answer whether the city can develop with a green-oriented design if this situation reversed. It was seen that the KTU Kanuni Campus, remained in the city center with the development of the city, was designed in harmony with the geography, topography and climate of the city in terms of basic settlement decisions and set a good example of green-oriented design.
\end{abstract}

Keywords: Heat Island, Green-Oriented Planning, Trabzon, KTU Kanuni Campus

\footnotetext{
*Sorumlu Yazar (Corresponding Author):

Derya ELMALI ŞEN (Doç. Dr.); Karadeniz Teknik Üniversitesi, Mimarlık Fakültesi,

Mimarlık Bölümü, 61080, Trabzon-Türkiye. Tel: +90 (462) 3771650, E-mail:

d_elmali@ktu.edu.tr, ORCID:0000-0003-1931-8927
}

Geliş (Received): 25.09.2020

Kabul (Accepted): 30.01 .2021

Basim (Published) : 15.04.2021 


\section{Giriş}

Günümüz dünyası; doğal kaynakların tükenmesi, hava kirliliği, su kirliliği, gürültü kirliliği, kimyasal kazalar, buzulların erimesi ve ekolojik dengenin bozulması gibi bir dizi çevresel sorunla karşı karşıyadır. Tüm bunların başında gelen en önemli sorun; küresel ısınma ve iklim değişikliği tehlikesidir. Bu sorunlarla birlikte endüstri devrimi sonrasında değişen üretim şekli, buna bağlı gelişen insan gereksinimleri ve bütün bunları karşılayabilmek için ihtiyaç duyulan enerjiyi elde etme problemi de günümüz dünyasının ivmeyle yükselen sorunlarındandır ve bu yönüyle çevresel sorunların hız kesmeden artmasına sebep olmaktadırlar. Çevresel sorunların temelinde ise üretim ve tüketim faaliyetlerinin yanı sıra hızla yapılaşan kentler yer almaktadır.

Endüstri devrimi sonrası değişen üretim şekilleri ve bu yeni üretim için gerekli iş gücü sağlama ihtiyacı kısa sürede kentlere gelen nüfus sayısının artmasına sebep olmuştur. Kentlerde nüfus artışının dünya geneline yayılması ise İkinci Dünya Savaşı sonrasında olmuştur. 1950’de \%29 olan dünya kentleşme oranı, 1975'te \%8,4 artışla \%37,4 ve 2000 yılında \%9,7 daha ivmeli bir artışla \%47,1 olmuştur (Demir ve Çabuk, 2010). 2008 yılında dünya nüfusunun \%50'si kentlerde yaşamaktadır ve 2030 yılında bu oranın \%60 olacağ öngörülmektedir (Munier, 2007). Ülkemizde ise, Çevre ve Şehircilik Bakanlığı'nın Aralık 2014 tarihli Türkiye Habitat III Ulusal Raporu'na göre, dünyadaki gelişmeye paralel olarak, kentlerde yaşayan nüfusun oranı 1950'de \%25 iken, 1980'de \%44'e, 2000'de \%65'e çıkmıştır. 2012 yllında ise bu oran \%77'ye yükselmiştir (URL-1, 2020). Söz konusu hızlı nüfus artışının kentler üzerindeki olumsuz etkisi; plansız, rastgele ve hızlı yapılaşma biçiminde diğer bir ifade ile çarpık kentleşme olarak kendini göstermiştir.

Hızla yapılaşan kentler, plansız programsız gelişmenin sonucunda bir dizi sorunu beraberinde getirmektedir. Artan nüfusu istihdam etmek için sanayi yapılarının yapılması, barınma ihtiyacını karşılamak üzere yeşil alanların yerleşime açılması, ihtiyaç olan ulaşım ağlarının yapılandırılmasında doğal dokunun tahrip edilmesi gibi gelişmeler, çeşitli şekillerde doğal döngüye zarar vererek temelde ekosistemin bozulmasına yol açmaktadır. Örnek vermek gerekirse, doğal çevreye oranla daha yoğun olan yapılı çevrelerin sert yüzey etkisi, mikro iklimlerde sıcaklık artışına ve nihayetinde kentsel ısı adalarının oluşmasına sebep olmaktadır. Kentsel ısı adaları olarak tanımlanan alanlar, binaların yoğun ve sert yüzeyin fazla olduğu buna karşılık yeşilin az olduğu kent parçalarıdır. Gün boyu 1sıyı emen yüzeyler, gün batımından sonra emdiği ısıyı dışarı yansıtarak yoğun yapılaşma olan alanlarda 1sı adaları oluştururlar. Bunun yanı sıra kent içi yeşil doku varlığının azlığı ya da yokluğu, yoğun kent dokusunun nefes almasını ve rahatlamasını engelleyerek, içte hapsolan ısının çepere göre daha yoğun hissedilmesine neden olur. Noktasal gibi görünen bu olumsuzluklar, sistemler bütünü olan dünyamızda, sistemlerin aksamasına sebep olmaktadır. Bu durum dünyanın karşısına küresel iklim değişikliği adıyla büyük bir çevre sorunu olarak çıkmaktadır.

Dünyayı tehdit eden bu olumsuz etkinin giderilmesi için tüm dünyada yeşil odaklı tasarım anlayışıyla kentlerin şekillendirilmesi konusunda ortak görüş vardır ve uluslararası anlaşmalarla bu yaklaşım desteklenmektedir. Söz edilen yeşil odaklı tasarım, "ekolojik" veya "çevresel açıdan duyarlı" veya "olumlu tasarım” veya çoğunlukla "eko-tasarım" gibi terimlerle ifade edilse de son yıllarda yerini "sürdürülebilir tasarıma" bırakmıştır (Madge, 2009).

Sürdürülebilirlik; uluslararası platformda Birleşmiş Milletler Çevre ve Kalkınma Komisyonu (WCED) tarafından 1987'de hazırlanan Brundtland Raporu'nda dünyanın gelecek kuşakların gereksinimlerine cevap verme yeteneğini tehlikeye atmadan, günlük ihtiyaçlarını karşılamak olarak ifade edilmiştir (URL-2, 2013).

Bu bağlamda sürdürülebilir tasarım, en yalın haliyle dünyaya zarar vermeden insan ihtiyaçlarını karşılayabilen tasarımdır. Bu tasarım yaklaşımı çevreye, yere ve iklime duyarlı; dünün ve bugünün geleceğe aktarımını önemseyen bir anlayışa sahiptir. Bu yaklaşımla geliştirilen ulusal ve uluslararası çalışmalarda; kentsel tasarım ilkeleri, kentsel uygulamalar ve kentsel tasarım rehberleri gibi yapılı çevrenin gelişimini tanımlayan ve yönlendiren uygulamalar ve ilkelerde; çevresel olumsuzlukların azaltılması, ekoloji ve biyoçeşitliliğin korunması ve yaşanılabilir kaliteli çevreler üretilmesi için yeşil planlama yapılması gerektiği vurgulanmaktadır.

Son dönemlerde, hızla yapılaşan çevrenin olumsuz etkilerini gidermek üzere yapı yüzeylerinde gerçekleştirilen yeşil doku uygulamaları dikkat çekmektedir. Bu uygulamalar "bitkilendirilmiş cephe" ya da "düşey cephe" ifadeleriyle bina cephelerinde; "yeşil çatı" ya da "çatı bahçesi”" tanımlarıyla çatı yüzeylerinde ya da "kat bahçeleri”" şeklinde zemin kotu dışındaki farklı konumlarda karşımıza çıkmaktadır (Şekil 1). 

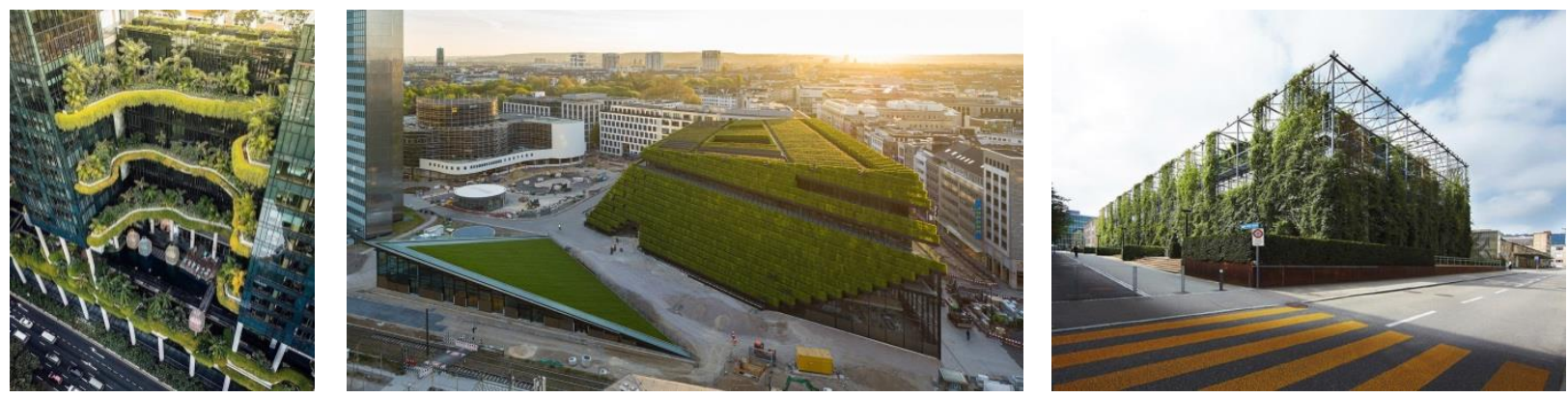

Şekil 1. Kat bahçeleri, yeşil çatı ve yeşil cephe uygulamaları (URL-3, 2020; URL-4, 2020; URL-5, 2020)

Ancak yeşil dokunun yapılı çevrenin herhangi bir yüzeyine yapıştırılmasından ya da eklemlenmesinden ziyade tabii halinde zeminde yer alması, toprağın ve yeşilin soğurucu özelliğinin daha kuvvetli etki etmesini sağlayacaktır. Bu durum her geçen gün sert yüzeyleri artan kentlerde, yağışların neden su baskınlarına yol açtığını da açıklamaktadır. Bu nedenle yapılı çevrenin yüzeylerinden önce zemin kotundan itibaren yeşil planlamanın düşünülmesi, alanın doluluk (yapılı çevre) - boşluk (yeşil doku) dengesi çerçevesinde kurgulanması gerekmektedir.

Dünya Sağlık Örgütü (WHO)'nün dünya kentleri arasında kişi başına düşen yeşil alan sıralamasında Viyana $120 \mathrm{~m}^{2}$ ile ilk sırada yer alırken; Viyana'yı sırasıyla 87,5 $\mathrm{m}^{2}$ ile Stockholm, $66 \mathrm{~m}^{2}$ ile Singapur, 45,5 $\mathrm{m}^{2}$ ile Amsterdam ve $27 \mathrm{~m}^{2}$ ile Londra takip etmektedir. Öte yandan 3 metrekarelik alanla Tokyo ve 1,9 metrekarelik alanla da Buenos Aires gibi kentler de kişi başına düşen yeşil alan miktarının azlığı ile dikkat çekmektedir (Bagherian, 2013; Karataş ve Kılıç, 2017).

Ülkemizde ise yeşil alan standardı ilk kez 1933-36 yılları arasında geçerli olan 2290 sayılı Belediye ve Yapı Yolları Kanunu ile yasal düzenlemelerde yer almış ve bu kanunda kişi başına düşen yeşil alan miktarı $4 \mathrm{~m}^{2}$ olarak belirlenmiştir. Ardından 1956-1985 yılları arasında geçerli olan 6785 sayılı İmar Kanunu’nda kişi başına düşen yeşil alan büyüklüğünün $7 \mathrm{~m}^{2}$ 'den az olamayacağı belirtilmiştir. 1999'da yayınlanan 23804 sayılı İmar Planı Yapılması ve Değişikliklerine Ait Esaslara Dair Yönetmelikte Değişiklik Yapılması Hakkında Yönetmelik ile kişi başına $7 \mathrm{~m}^{2}$ olan yeşil alan standard1 10 ${ }^{2}$ 'ye çıkarılmıştır (Aksoy, 2014). Bununla birlikte Çevre ve Şehircilik Bakanlığı'nın 14 Haziran 2014 tarihli Mekânsal Planlar Yapım Yönetmeliği’ne göre kişi başına düşmesi gereken yeşil alan; ilçe sınırları içinde yapılan planlarda $10 \mathrm{~m}^{2}$, il sınırları bütününde yapılan planlarda $5 \mathrm{~m}^{2}$ olmak üzere toplam $15 \mathrm{~m}^{2}$ olarak belirlenmiştir. Düzenlemeye göre yeşil alan kapsamını mahalle ölçeğinde çocuk bahçesi, park, meydan, semt spor alanları, botanik parkları, mesire yerleri ve rekreasyon kullanımları oluştururken; şehir bütünü ölçeğinde ise hayvanat bahçesi, kent ormanı, ağaçlandırılacak alan, fuar, panayır ve festival alanı ile hipodrom oluşturmaktadır (Şekil 2) (URL-6, 2020).

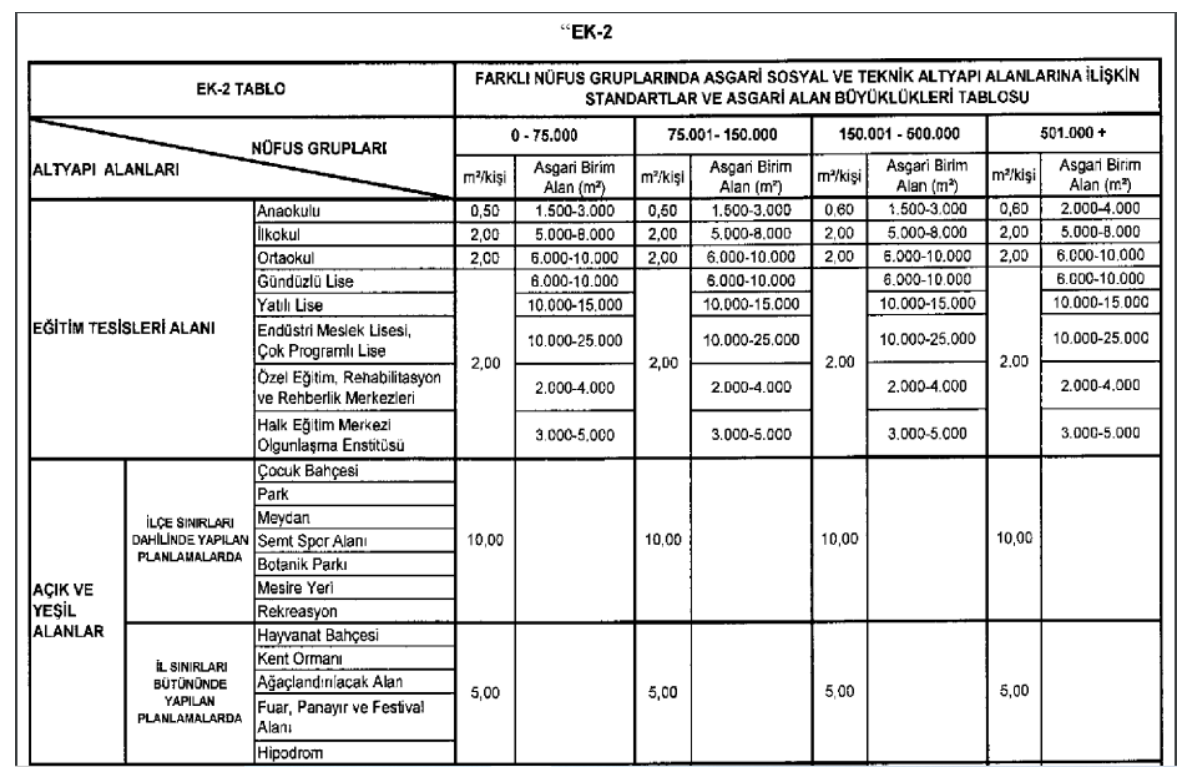

Şekil 2. ÇŞB Mekânsal Planlar Yapım Yönetmeliği’ne göre kişi başına düşmesi gereken yeşil alan büyüklüğü (URL-6, 2020) 


\section{Materyal ve Metot}

Çalışmada, yukarıda çerçevesi çizilen hızlı ve çarpık kentleşmenin baskısıyla olumsuz etkilenen birçok kent arasından Trabzon kenti konu edilmiştir. Bunun nedeni, Trabzon kent merkezinin öngörüsüz plan ve uygulamalar sonucunda küresel ısınma ve iklim değişikliği etkilerinin hissedildiği, hafif ve orta düzeyde kuraklık belirtileri gösteren ve giderek yeşil doku bakımından fakirleşen bir yerleşime dönüşmesidir. Peki, bu dönüşüm bölgenin dokusu ile uyumlu ve yeşil odaklı olarak sağlanamaz mıydı? Yoğun bir yerleşim olan kent dokusu; mikro iklimi iyileştirici, yeşilin sürekliliğinin sağlandığı daha ekolojik bir yaklaşımla ele alınabilse yaşanabilir kaliteli çevreler üretilebilir miydi? Çalışma kapsamında bu sorulara KTÜ Kanuni Kampüsü'nün yanıt olabileceği düşünülmüsstür. Trabzon kent merkezinde yer alan KTÜ Kanuni Kampüsü, kentin iklimine ve coğrafi yapısına uygun yeşil odaklı tasarımı ile kent için iyi bir örnek teşkil etmektedir. Bu bağlamda çalışmada, hızla yapılaşan Trabzon kenti için yeşil odaklı bir planlama örneği olarak KTÜ Kanuni Kampüsü’nün incelenmesi amaçlanmıştır. $\mathrm{Bu}$ amaçla öncelikle Kampüs içerisinden mevcut kent dokusuna benzer yapı yoğunluğuna sahip bir alan belirlenerek konumlanma ve doluluk-boşluk kurgusu, yol ve ulaşım bağlantıları ile yeşil dokunun varlığı ve sürekliliği açısından uydu görüntüleri üzerinden analiz edilmiş̧tir. Ardından Kampüse komşu olan Kalkınma Mahallesi’nde eşdeğer büyüklükte bir alan belirlenerek söz konusu iki alan yapısal yoğunluk açısından CAD ortamında hesaplamalar yoluyla karşılaştırılmıştır. Böylelikle Kampüste gerçekleştirilen olumlu uygulamanın kent parçası için de geçerli olup olmadığı araştırılmıştır.

\subsection{Trabzon Kenti}

Osmanlı'da toplumsal yapının dışa kapalı olması nedeniyle cami avluları ve çeşme meydanları dışında, şehir sokaklarında pek ağaç bulunmamakla birlikte şehrin yeşili evlerin bahçelerinde toplanmıştır (Kuban, 1995). Her evin kendine göre avuç içi büyüklüğünce de olsa bir bahçesi vardır (Bektaş, 2014). Ağaçlar bahçelerde bulunduğundan sokaklarda gölge veren ağaçlar yoktur. Bu nedenle Türk kentleri, sokakların içinden yeşil olarak algılanmaz ancak uzaktan ya da yukarıdan bakıldıklarında yeşil bir görünüm sergilerler (Kuban, 2018). Geleneksel dokuda yeşil, sokaklarda pek görülmese de evlerin mahremi olan bahçelerindeki yeşil doku kentte doluluk-boşluk dengesini sağlamaktadır. Buna ilaveten Aru (1988), Osmanlı döneminde mahallelerin; ağaç kümeleri, sebze bahçeleri ve bostanlarla birbirlerinden kesin bir şekilde ayrıldığına, mahalleler arası sınırın yeşil doku ile belirlendiğine dikkat çeker. $\mathrm{Bu}$ bağlamda geçmişe baktığımızda ülkemizdeki eski şehir yerleşimlerinde, her ne kadar planlı olmasa da yapılı çevrenin doğal çevre ile dengelendiği, doluluk-boşluk dengesinin gözetildiği görülmektedir. Bu eski yerleşimlerden birisi de Türkiye'nin Doğu Karadeniz Bölgesi’nde bulunan Trabzon kentidir. Doğal dokusu oldukça yeşil olan ve sürekli yağış alması ile bilinen bu şehir 2018'de en kurak dönemlerinden birini yaşamıştır. Meteoroloji Genel Müdürlüğü’nün Kuraklık Analizi raporlarına göre Trabzon merkez bölgesi, Eylül 2017 - Ağustos 2018 döneminde Türkiye'nin 34 kurak bölgesinden biri olmuştur (URL-7, 2020) (Şekil 3). Devam eden süreçte de (Temmuz 2018- Haziran 2020) Trabzon kent merkezinin kuraklık durumunu koruduğu görülmektedir (URL-8, 2020) (Şekil 4).

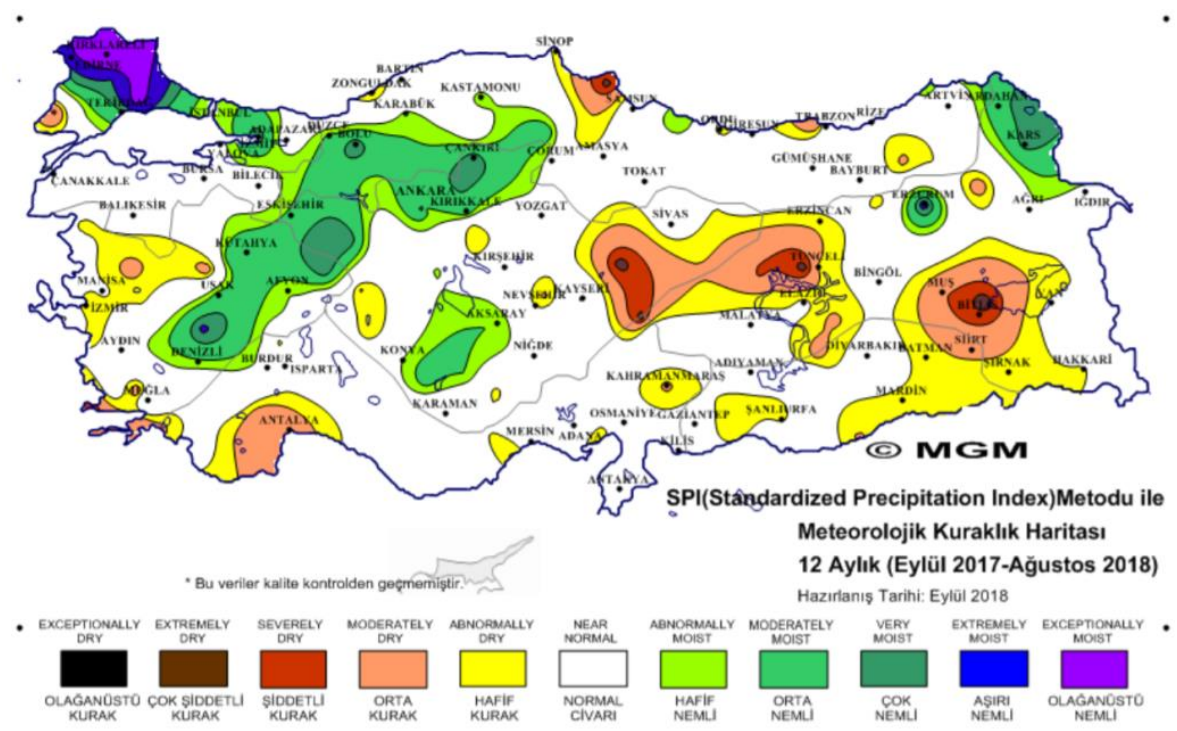

Şekil 3. Standart Yağış İndeksi (SPI) metoduna göre Meteorolojik Kuraklık Haritası, Eylül 2017- Ağustos 2018 (URL-7, 2020) 


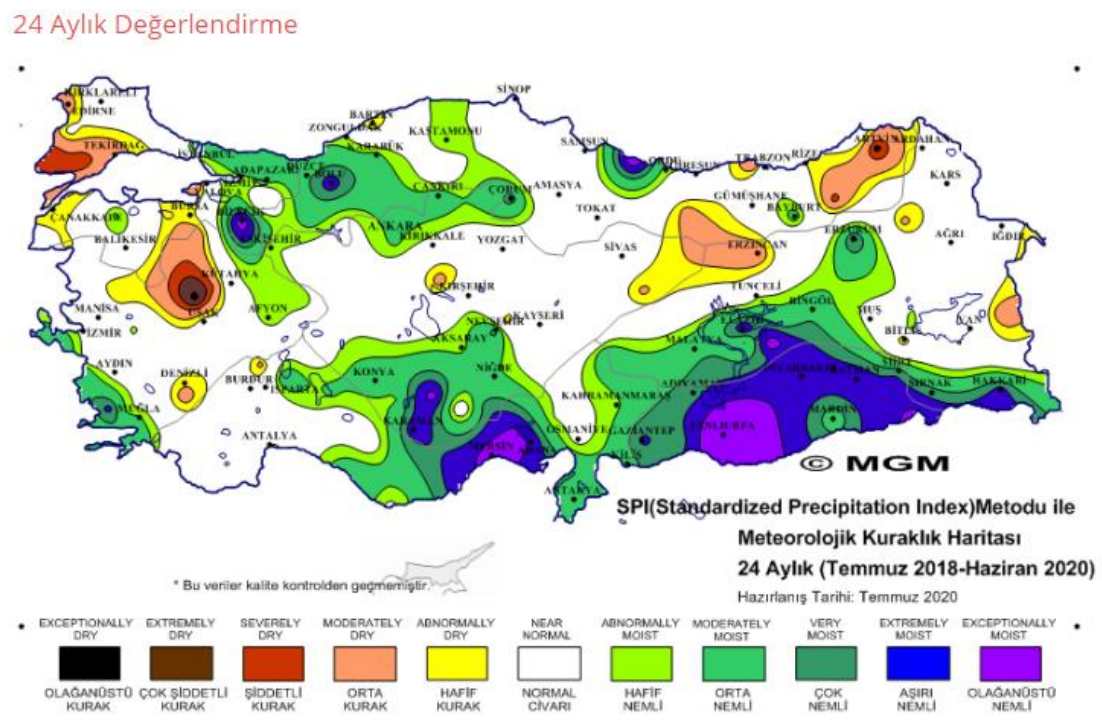

Şekil 4. Standart Yağıș İndeksi (SPI) metoduna göre Meteorolojik Kuraklık Haritası, Temmuz 2018 - Haziran 2020 (URL-8, 2020)

Bunun belki de en önemli sebebi hızla yapılaşan ve her geçen gün çehresi değişen kentin özellikle kent merkezinde doğal dokusunun yapılarla yok edilmesidir (Şekil 5 ve 6). Hızlı ve plansız yapılaşma ile orantısız derecede artan sert yüzeylerin yeşil doku ile dengelenmemesi durumunda mikro iklimde sicaklık artışına yol açtığı bilinmektedir. Sert yüzey yoğunluğuna bağlı olarak sıcaklık artışı ve 1sı adalarının oluşumu, kent merkezindeki yağış oranının azalmasına ve söz konusu kuraklığa yol açan temel nedenler arasında sayılabilir.

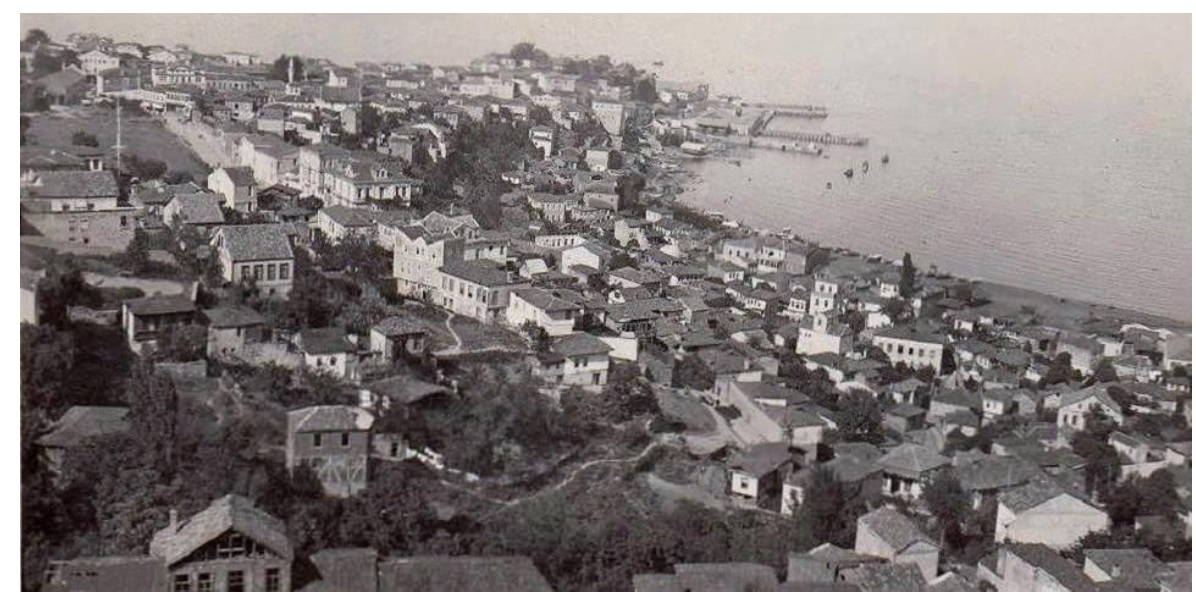

Şekil 5. Eski Trabzon, 1977 (URL-9, 2020)

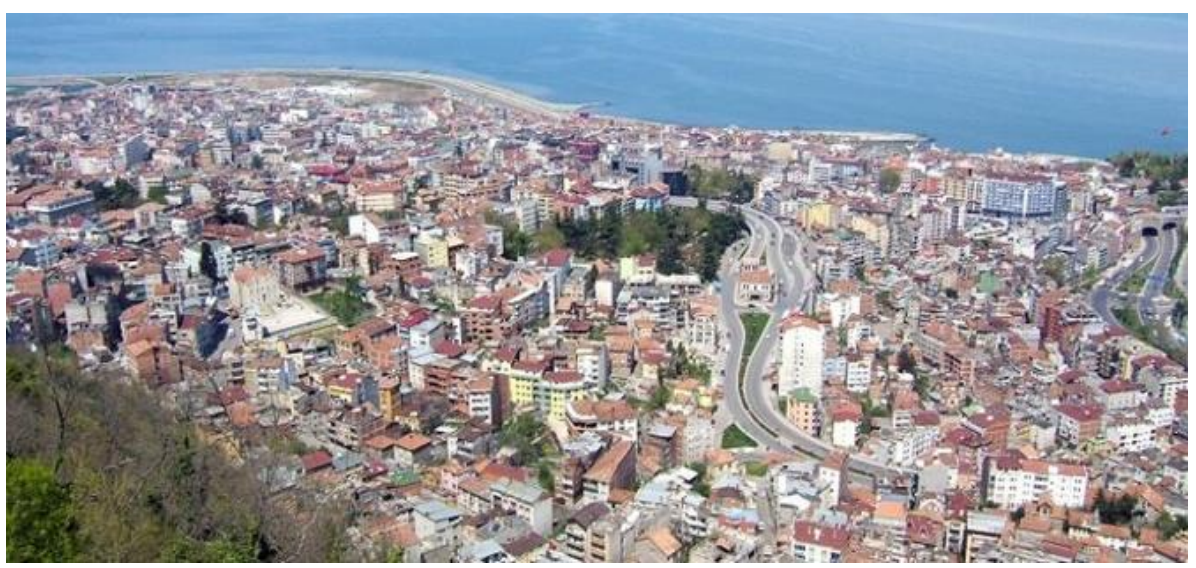

Şekil 6. Trabzon yeni yapılaşma, 2018 (URL-10, 2020) 
Trabzon; geçmişte çoğu Osmanlı Şehri gibi, kent merkezi dar sokaklar boyunca uzanan, bahçeli konutların bulunduğu, yeşil dokunun sürekliliğinin sağlandığı mahallelerden oluşmaktaydı. Dışa kapalı bahçeli konut düzeni; 1840'ta Trabzon'u ziyaret eden Alman tarihçi ve seyyah J. P. Fallmerayer'in de dikkatini çekmiş ve seyahat notlarında şu şekilde yer almıştır (Usta, 1999):

“... Ev Trabzon’da gelenek olduğu üzere, sokak boyunca ilerleyen bir duvarın içindedir. Bununla ev yaşamının yoldan gelip geçenlerin görüş alanından uzak tutulması amaçlanmaktadır. Buradaki sokaklar, Avrupa'da alışık olduğumuz gibi evlerin cepheleri tarafindan oluşmamakta; çarşı hariç olmak üzere sokakları bahçe duvarları meydan getirmekte; duvarlarla evler arası yeşillendirilmekte veya taş döşenmektedir. Ev, bahçede yer alan zincirli kuyu ve ağaçların arkasında kalmaktadır."

Ancak o günlerden günümüze kadar geçen sürede özellikle 1980li y1llardan sonra kentleşme adına yaşanan gelişmeler Trabzon'da etkisini göstermiştir. Hızlı gelişimin yol açtığı en büyük sorun, bahçeli nizamda sıralı devam eden konutların yerini çok katlı apartmanların almasının ötesinde, bahçeli konut parselinin tamamının yeni yapılan apartmanların taban alanı olarak ele alınması ve bu sıralı konutları bitişik nizam, çok katlı yapılara dönüşmesidir. $\mathrm{Bu}$ durum, yapılar dönüştürülürken söz konusu alandaki doluluk-boşluk oranının dikkate alınmadığını ifade etmektedir. Yeni doku aynı parsel sınırları içerisinde, aynı genişlikteki yolu kullanmıştır. Yapıların kat sayıları artıp yapılar arası mesafe değişmediğinden güneş 1şınımı sekteye uğramış, önceden geçerli olan doğal aydınlanma ve 1sınma açıları ile süreleri olumsuz yönde değişmiştir. Bununla birlikte yeni doku, yeşil alanın korunmadığı, daha geniş taban alanına yayılan çok katlı bir düzenle, daha yoğun bir yapı kitlesi şeklinde inşa edilmiştir (Şekil 7).

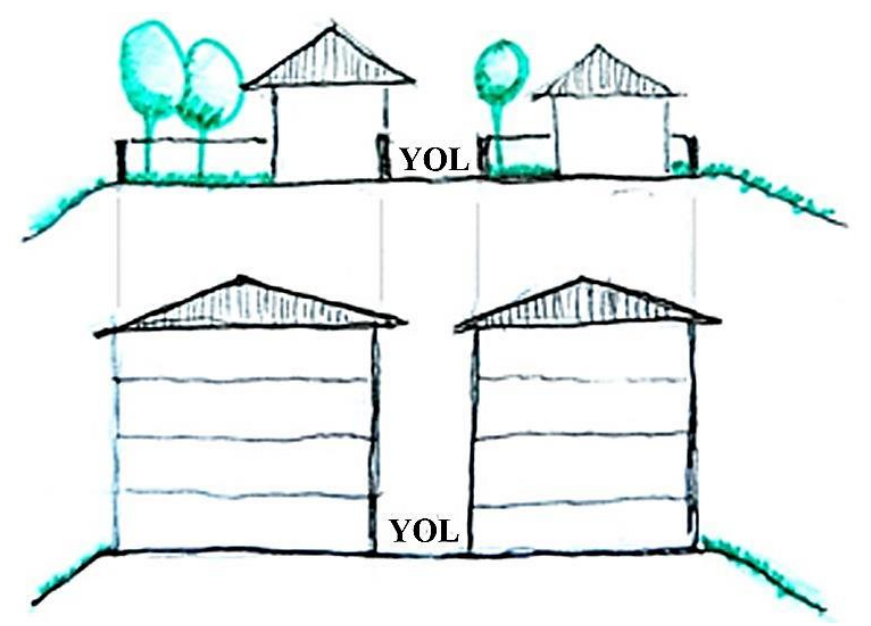

Şekil 7.Eski dokunun yeni dokuya dönüşümü (Çizim: Elif Öztürk)

Peki, bu dönüşüm bölgenin dokusu ile uyumlu ve yeşil odaklı olarak sağlanamaz mıydı?

Çalışma kapsamında bu soruya Trabzon merkez ilçesinde yer alan, kentin geleneksel dokusundaki dolulukboşluk dengesini ve yeşilin sürekliliği sağlayan; yere, iklime ve araziye uyumlu üretilen yapılı çevrelerle aynı ilkeler ile kurgulanan ve fakat günümüz ihtiyaçları ve yapım tekniklerine uygun yapılan KTÜ Kanuni Kampüsü'nün yanıt olabileceği düşünülmüştür.

\subsection{KTÜ Kanuni Kampüsü}

25 Mayıs 1955 tarihinde 6594 sayılı kanunla Karadeniz Teknik Üniversitesi'nin kurulması kabul edilmiştir ancak üniversitenin öğretime başlaması 19 Eylül 1963 yılında 336 sayılı ek kanunla birlikte olmuştur. Bu kararın ardından 28 Mart 1962 yılında KTÜ Kanuni Kampüsü (Merkez Kampüs); Temel Bilimler Fakültesi, İnşaat ve Mimarlık Fakültesi, İnşaat Fakültesi Laboratuvarları, Makine Fakültesi, Elektrik Fakültesi, Orman Fakültesi, Yer Bilimleri Fakültesi, İdari binalar, Kapalı Spor Salonu, Öğrenci Lokali, Çarşı binası, Yurtlar ve Lojmanları içeren bir ihtiyaç programı ile yarışmaya açılmıştır. İlk beşe giren projeler arasında, jüri tavsiyeleri doğrultusunda tekrar hazırlanarak ikinci bir yarışma yapılmıştır. 15 Şubat 1963 yılında sonuçlanan yarışmayı bu beş proje içerisinden yüksek mimarlar Mustafa Polatoğlu ve Nihat Güner'in hazırladıkları kampüs projesi kazanmıştır. Mimarlar kampüs tasarımını, kampüsün kentle ilişkisi, trafik, manzara, iklim ve arazi verileri bağlamında şekillendirmişlerdir (Polatoğlu, 1971) (Şekil 8). 


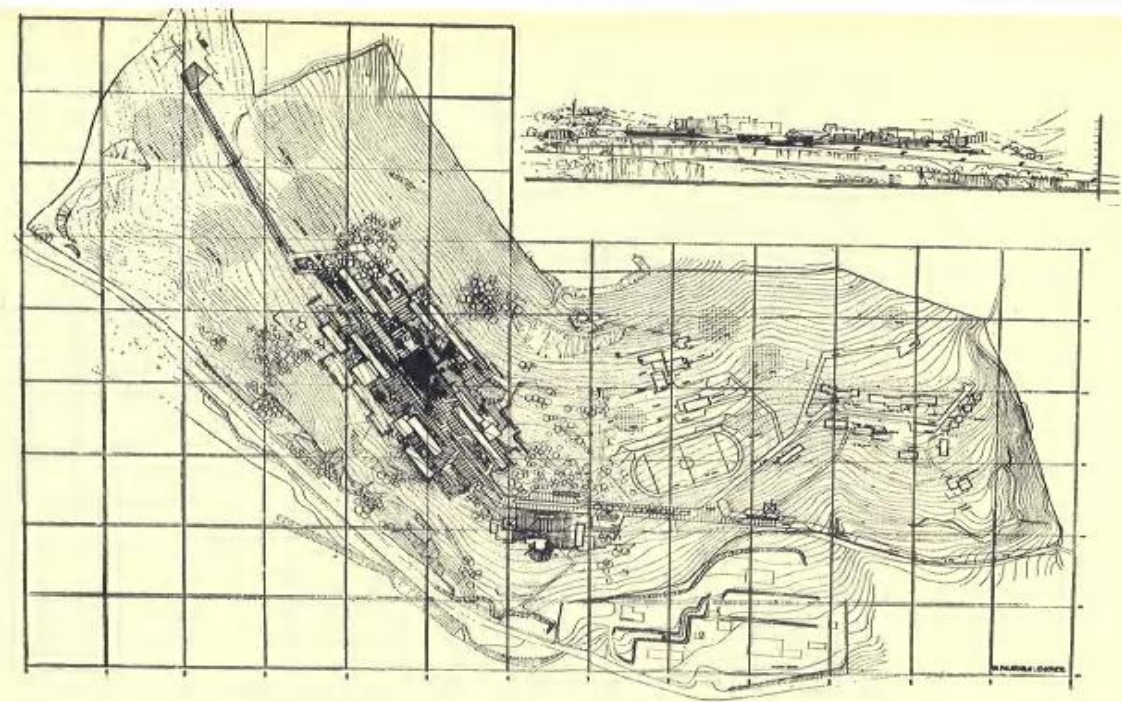

Şekil 8. KTÜ Kanuni Kampüsü proje yarışmasını kazanan proje (Polatoğlu, 1971)

Kampüs arazisi batıya ve doğuya bakan iki yamaç üzerindedir. Bu iki yamacın kuzeye bakan mafsal noktasında işlevler ayrılmış, fakülteler doğu yamacında diğer yapılar batı yamacında konumlandırılmıştır. KTÜ Kanuni Kampüsü projesi Trabzon'un yerleşim geleneğindeki prensiple kurgulanmıştır. Proje kurgusu arazi eğrilerine paralel yerleştirilen ana yol aksı ve etrafinda konumlanan yapılar şeklindedir. Alanda dolulukları oluşturan yapılar arasında kalan boşluklar; yer yer avlu, meydancık, otopark ve yeşil doku olarak düzenlenmiş ve korunmuştur. $\mathrm{Bu}$ yerleşim düzeni aynı zamanda eğimli topoğrafyaya sahip Trabzon'a en uygun yerleşim şeklidir.Bu bağlamda, sürdürülebilir diğer bir ifade ile "Dünyadan daha az alan ve insanlara daha çok veren" (URL-11, 2013) yapılı çevrelerin Trabzon kentinde uygulanabilmesi için, KTÜ Kanuni Kampüsü’nün yeşil odaklı bir örnek olarak ele alınabileceği ve temel yerleşim kararlarının incelenerek elde edilecek çıkarımlardan yararlanılabileceği düşünülmüştür. Çalışmada, kentteki yoğun yerleşke dokusuna karşılık gelebilecek, yol boyu gelişen ve KTÜ Kanuni Kampüsü'ndeki en yoğun yapılı alanı olan Fakülteler bölgesi, yeşil odaklı tasarlanmış kent parçası olarak ele alınmıştır. Ayrıca fakülteleri oluşturan bölüm yapılarının bir araya getirilerek grup oluşturulması ve bu yapıların ortak kamusal kullanım alanlarından yararlanması, bu gruplamaların mahalle ölçeğinde komşuluk birimlerine karşılık gelebileceği düşüncesini akla getirmiştir (Şekil 9). Bu bağlamda çalışma alanı, üniversitenin ana omurgası/ aksı üzerinde yer alan ve ilk fakülte yerleşimlerini içeren bölge ile sınırlandırılmış ve sonradan eklenen İktisadi ve İdari Bilimler Fakültesi ve Hukuk Fakültesi gibi birimler çalışma alanı dışında bırakılmıştır (Şekil 10).

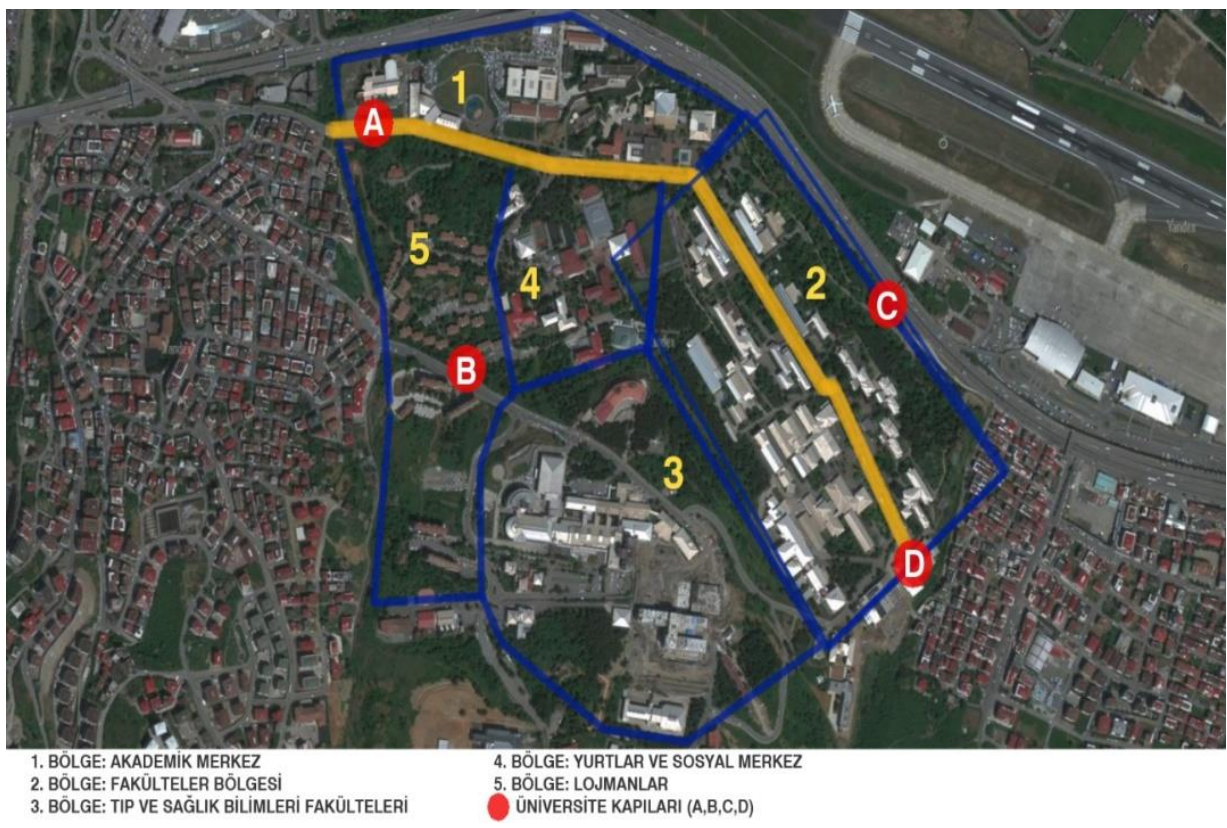

Şekil 9. KTÜ Kanuni Kampüsü ana aks üzerindeki yerleşim ve fakülteler bölgesi 


\section{Bulgular ve Tartışma}

Çalışma kapsamında KTÜ Kanuni Kampüsü’nün fakülteler bölgesini içeren yapılı çevre kurgusu diğer bir ifadeyle temel yerleşim kararları; doluluk-boşluk dengesi, yol ve ulaşım bağlantıları, yeşil dokunun varlığı ve sürekliliği bağlamlarında incelenmiştir.

Konumlanma ve doluluk-boşluk dengesine ilişkin kararlar;

- Doğal yeşil doku içerisinde, arazi eğimine paralel, doğu-batı doğrultusunda uzanan ulaşım aksının ana omurga olarak konumlanması (Şekil 10)

- Yapı / yapı gruplarının ana ulaşım aksı ile bağlantılı biçimde, aksa ve eğime paralel konumda yol boyu sıralanması (Şekil 10)

- Yapı gruplarının bir araya gelişlerinde ve birbirlerine göre konumlanmalarında, havalandırmaya imkân tanıyan doluluk-boşluk dengesinin sağlanması (Şekil 10)

- Yapı formu olarak dar ve uzun kütle seçimleri ile nemli iklime uygun biçimlenme (Şekil 10)

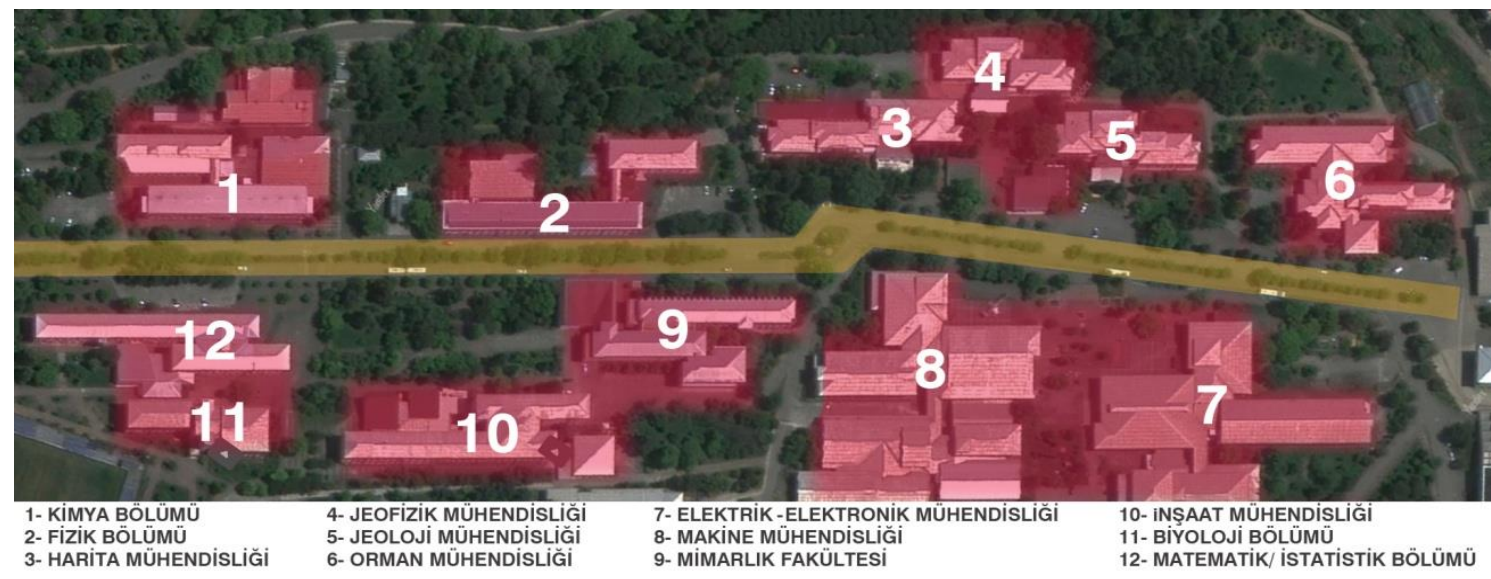

Şekil 10. Ana yol aksı boyunca yapı yerleşimi

- Bina grupları arasında oluşan avlu ve meydancıkların istenmeyen rüzgâr yönü olan kuzeybatı yönünde konumlandırılmaması. (Fakülteler bölgesinin yerleşkenin doğu yamacında yer alması, bu alanı istenmeyen rüzgâr yönünden korumaktadır. Yine de bu yönden gelen rüzgâra karşı yapılar, yeşil doku ve kot farkı ile önlem alınmıştır. Ayrıca avlular güneşlenme yönüne açılmaktadır.) (Şekil 11)

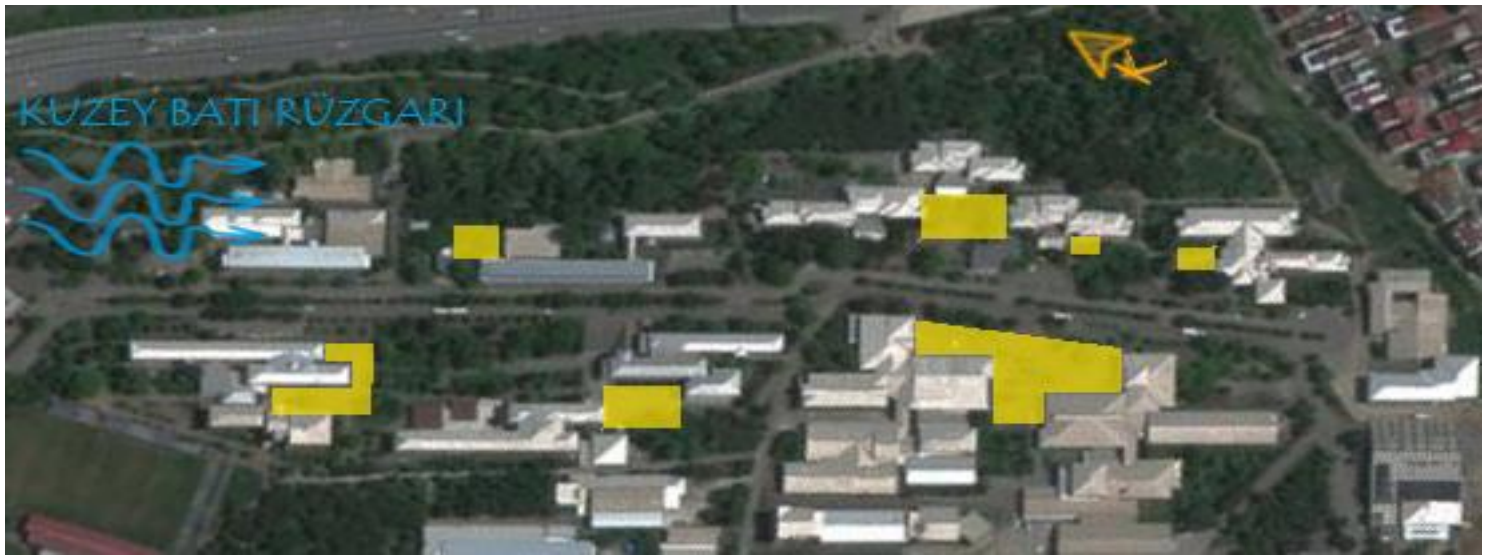

Şekil 11. Avluların konumlanması

- Yapıların birbirlerine göre konumlanması ile aralarda ortak kullanım alanlarının oluşması (kamusal açık alanlar/ ortak kullanılan avlular/ meydancıklar) (Şekil 12)

- Bina gruplarının kullandığı kamusal açık alanlar dışında kalan alanlarda, doğal eğimi ve yeşili korunan pasif yeşil alanların bırakılması (Şekil 12)

- Bina grupları içerisinde yaya yolları ve/ veya kamusal açık alanlarla ilişkili yeşil alanlar kurgulanması (Şekil 12) 


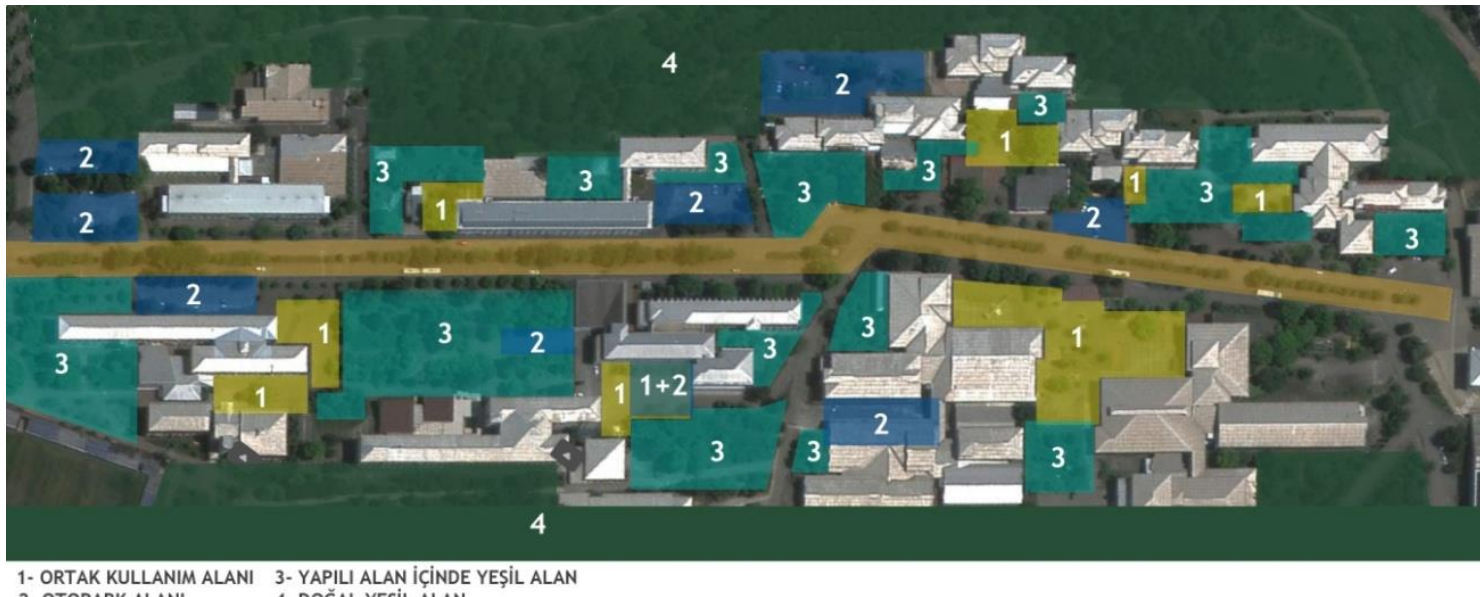

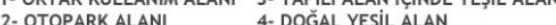

Şekil 12. Doluluk- boşluk düzeninde boşluklar ve işlevleri

Yol ve ulaşım bağlantılarına ilişkin kararlar;

- Ana akstan ortak kamusal açık alanlara ulaşımda farklı alternatiflerin sunulması

- Ana aks >Otopark alanı> Kamusal açık alan (meydancık)

- Ana aks > Kamusal açık alan (meydancık)

- Ana aks> Tali yol bağlantısı > Kamusal açık alan (meydancık)

- Bina girişlerinin, hem ana aksla hem de kamusal açık alanlarla ilişkilendirilmesi ve ayrıca farklı kotlardan alınan girişlerle binalara ulaşımda farklı alternatiflerin sunulması

Yeşil dokunun varlığı ve sürekliliğine ilişkin kararlar (Şekil 13);

- Doğu-batı doğrultusunda ana yolla ilişkili gelişen yapılı çevre aksının kuzeyinde ve güneyinde orman alanlarının bulunması

- Yapı grupları arasında bulunan boşluklarda ağaçlık alan düzenlenmesi ve pasif boşlukların ağaçlandırılması ile orman alanlarında doluluk-boşluk iliş̧isinin kurulması

- Yapı grupları arasında yeşille ilişkili düzenlenen kamusal açık alanlar ile yeşilin sürekliliğinin sağlanmas

- Yapı grupları ile ilişkili otopark alanlarında ağaçlandırma ile yeşilin sürekliliğinin sağlanması

- Ana ulaşım aksına cephesi olan yapıların önlerinde, yaya yolları ve yol aksındaki orta refüjde sıra ağaçlandırma yapılarak yine yeşilin sürekliliğinin sağlanması

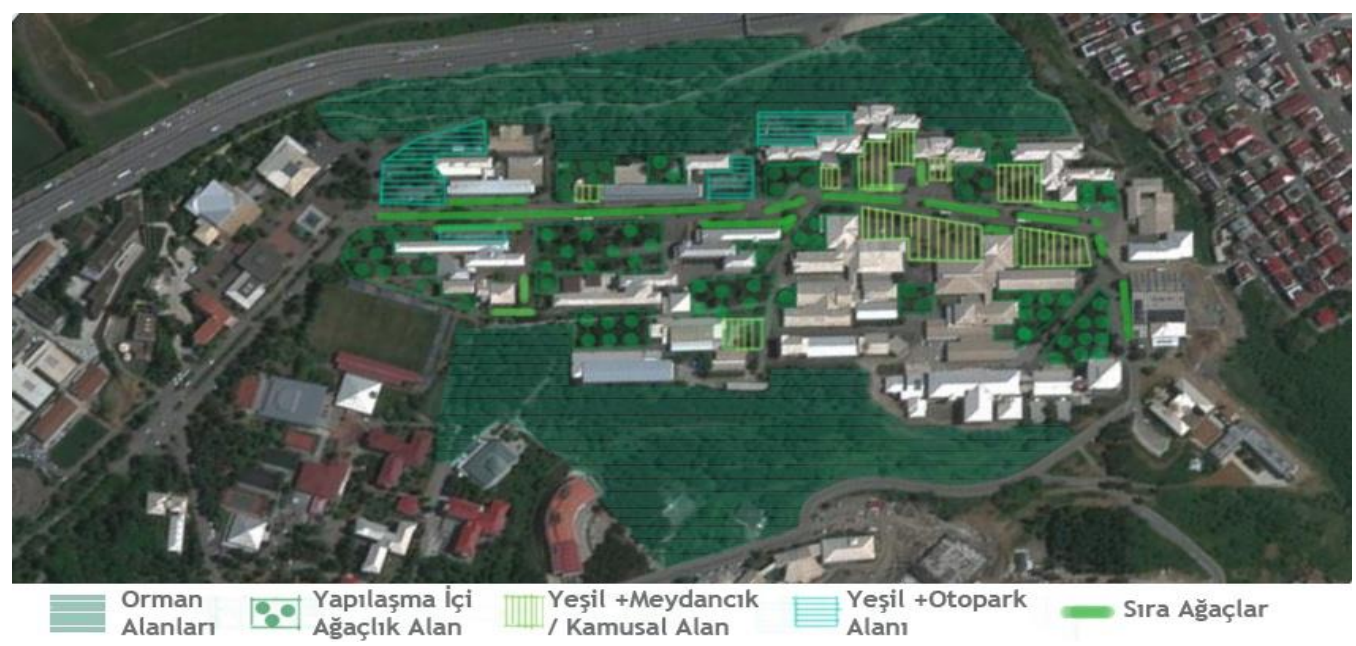

Şekil 13. Yeşilin farklı konumlarda ve niteliklerde sürekliliğinin sağlanması

Yoğun yapılaşma içeren mevcut kent dokusu; mikro iklimi iyileştirici, yeşilin sürekliliğinin sağlandığı daha ekolojik bir yaklaşımla ele alınmış olsa yaşanabilir kaliteli çevrelerin üretilmesi mümkün mü̈ür?

$\mathrm{Bu}$ soruya cevap aramak için çalışmanın bu kısmında, Kanuni yerleşke alanına komşu olan ve hızla yapılaşan kent karakteri ile uyumlu bir yerleşim olan Kalkınma Mahallesinde bir alan seçilmiştir. Kıyaslamanın sağlkklı 
olabilmesi için seçilen alanın, KTÜ Kanuni Kampüsü Fakülteler Bölgesinde belirlenen çalışma alanı ile aynı büyüklükte olmasına dikkat edilmiştir. Söz konusu iki alan, doluluk-boşluk dengesi ve yapı yoğunluğu bakımından karşılaştırılmıştır (Şekil 14).

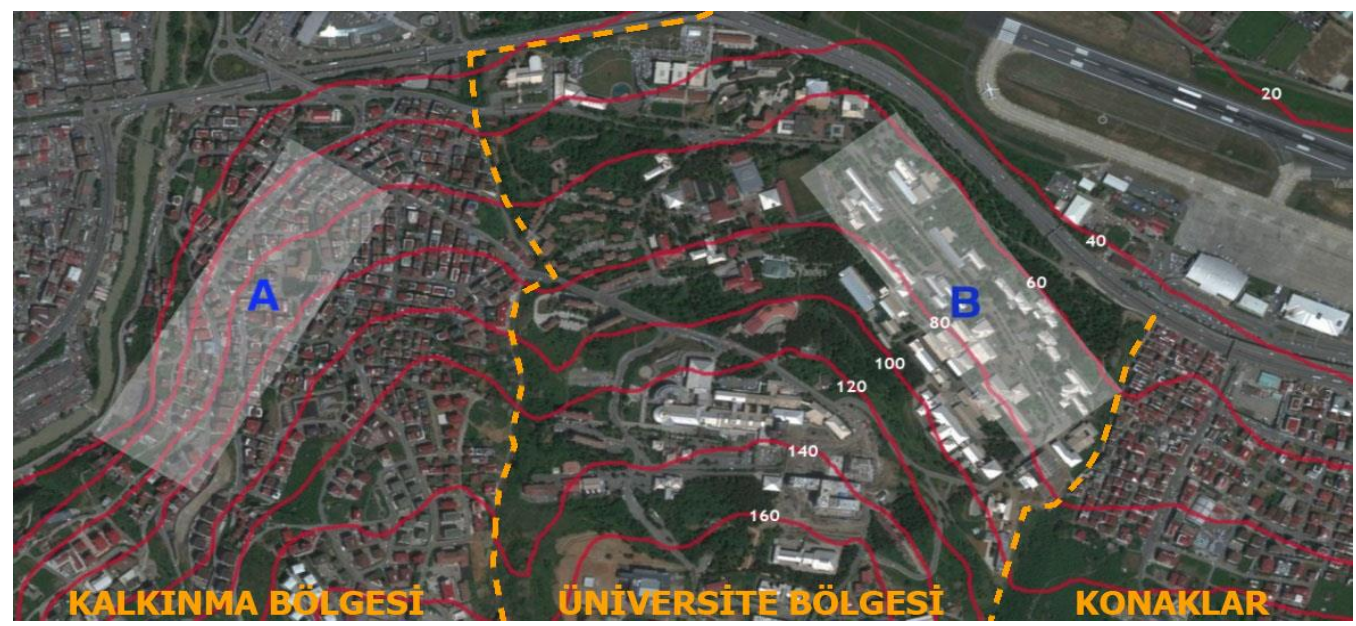

Şekil 14 A) Kalkınma Mahallesi’nde seçilen alan, B) KTÜ Kanuni Kampüsü Fakülteler bölgesi

Kalkınma Mahallesi; Kanuni Kampüsünün batısında ve kampüse komşu konumunda bulunan, önceleri kırsal nitelikte olan bir bölgedir. Zaman içerisinde üniversiteye yakın konumu, üniversiteye gelenlerin barınma ihtiyacını karşılamak üzere tercih nedeni olmuş ve barınma gereksinimi bu bölgeye yerleşim talebini artırmıştır. Bu durum bölgeyi yüksek rantlı bir alan haline getirmiştir. Böylece Kalkınma Mahallesi’nde kısa sürede, hızlı ve plansız bir yapılaşma gelişmiştir. Mahalledeki yapılar, ya bitişik nizamda ya da birbirlerine çok yakın, iç içe ve çarpık bir düzende inşa edilmiştir. Yapıların farklı kat yüksekliklerine sahip olduğu alanda, yükseklik profili de düzensizlik göstermektedir. Arsa sınırlarını zorlayan yapılar, dar kaldırımlar ve taşıt yolları boyunca devam etmektedir (Şekil 15). Bölge, yeşilden yoksun yol-konut dizilimleriyle hem zeminde hem de üçüncü boyutta sert yüzeylerle şekillenmiştir. Sert yüzeyin fazla olması mikro iklimin olumsuz yönde değişmesine neden olmaktadır. Bu sert yüzey sürekliliği içerisinde atıl kalan küçük alanlardaki yeşil alan parçaları ve küçük bahçelere sahip az sayıdaki yapının yeşil alanları, bölgenin yapılı alanları ile oranlandığında, Kalkınma bölgesindeki yeşil alanın yok denecek kadar az olduğu görülmektedir (Şekil 14).

Doluluk-boşluk dengesizliğinin yanı sıra araziye uygun olmayan ve sıkışık yerleşim düzeni, Kalkınma bölgesinde iklim elemanlarının olumlu etkilerinden yararlanılamamasına neden olmaktadır. Tüm bunlara ek olarak eğimli arazi yapısına sahip bölgedeki yapıların, araziyi boşaltma yöntemiyle inşa edilmesi ile zaten nemli olan havaya bir de toprağın nemi eklenmektedir. Bu durum hava kalitesinden yoksun rutubetli yaşam alanları üretilmesine sebep olmuştur. Yapı yoğunluğu, sert yüzeyin fazla oluşu ve doluluk-boşluk dengesizliği, nemin giderilmesini sağlayacak olan güneş etkisini ve rüzgâr hareketini de engellemektedir. Bu kaotik yapılaşma, yaşanılabilir çevre üretme bakımından hem kalitesiz çevre oluşmasına, hem de mikro iklimde dış ve iç mekân iklim konfor koşullarından yoksun bir konut alanı oluşmasına neden olmaktadır. Bu yönleriyle Kalkınma bölgesi Trabzon kentinde hızla yapılaşan alanlarla benzer gelişim göstermektedir ve aynı karaktere sahiptir. Bu bağlamda yeşil Trabzon şehrinin yeşil olmayan merkezi, yeşil planlama ile gelişebilir miydi sorusuna; üniversite yerleşkesi ve Kalkınma bölgesi, yeşil planlama ve doluluk-boşluk dengesi bakımından kıyaslanarak cevap aranmıştır.

$\mathrm{Bu}$ iki alanın yapılarının bir araya gelişleri ve oluşturdukları yapılı çevrenin mevcut durumuna dair görseller Şekil 15 ve Şekil 16'da verilmektedir. Bu görseller yaşanabilir kaliteli çevre bakımından da (yeşil doku, doluluk-boşluk dengesi, taşıt ve yaya erişsimi vb.) iki alan arasındaki nitelik farkını göstermektedir. Ayrıca Şekil 9 ve Şekil 14'teki görsellerde KTÜ Kampüs alanı ile çevreleyen kent dokusu arasındaki yeşil doku farkını gözlemlemek de mümkündür. 


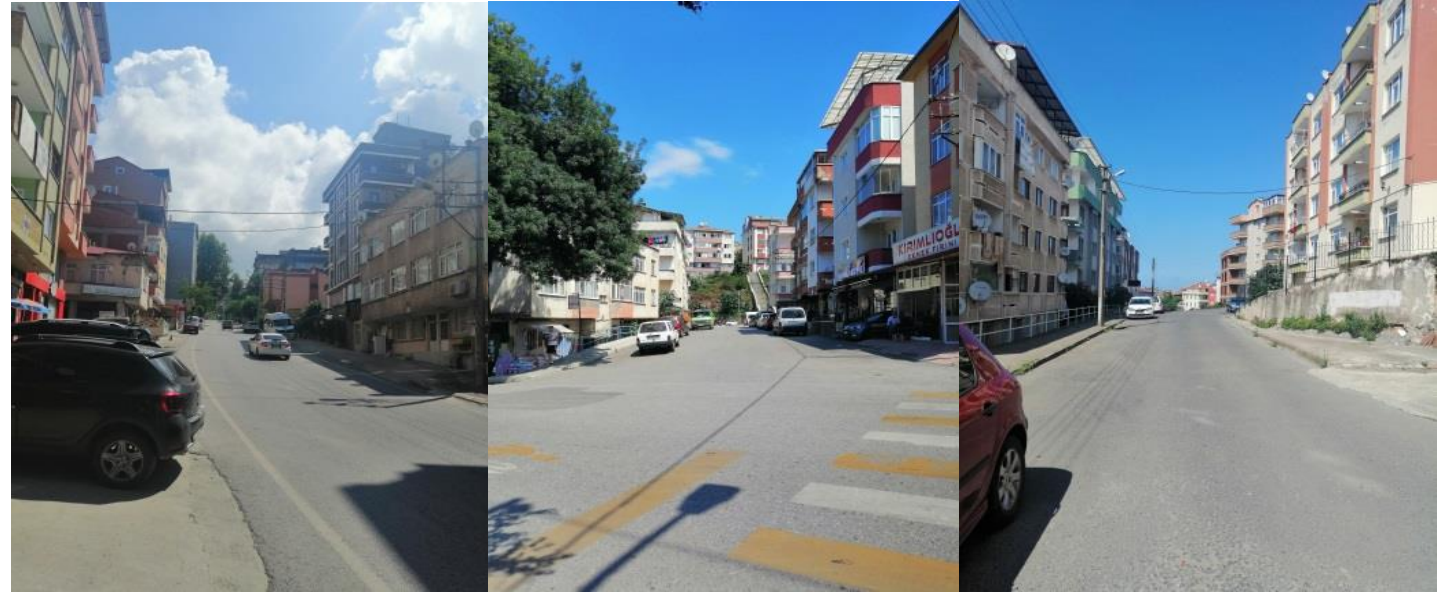

Şekil 15.Kalkınma Mahallesi seçilen alan

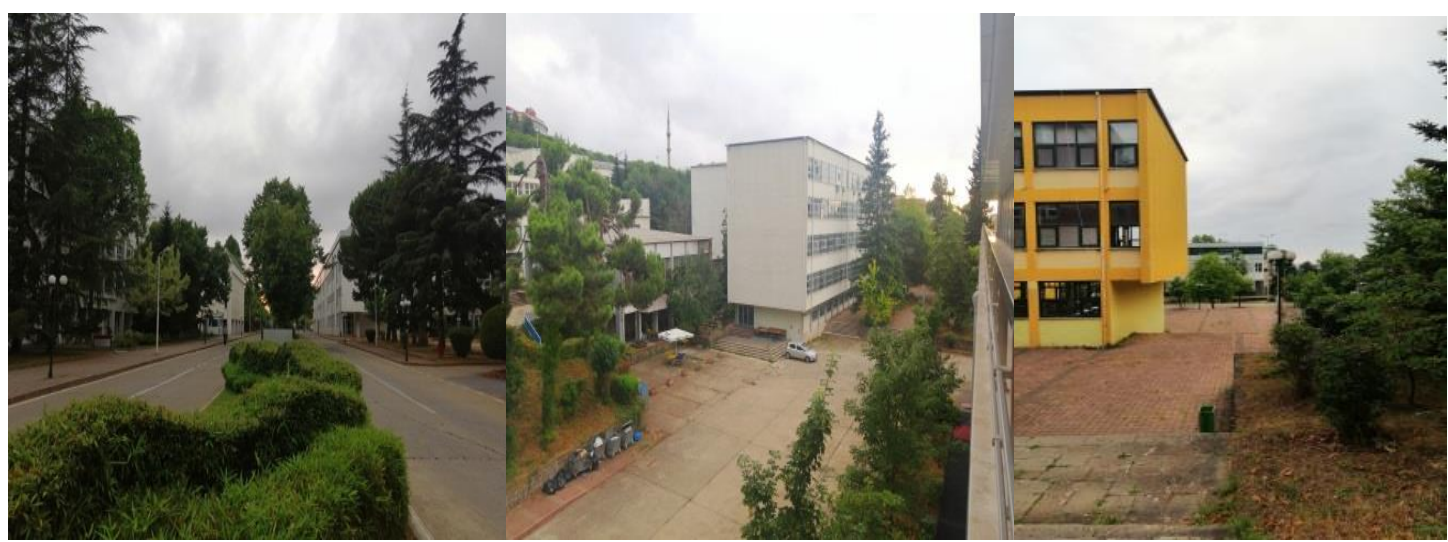

Şekil 15. KTÜ Kanuni Kampüsü Fakülteler bölgesi

Bu karşılaştırmanın yapılmasındaki temel amaç, Kampüs alanındaki yapı yoğunluğunun kentsel alandaki yapı gereksinimini ne ölçüde karşılayabileceğini ortaya koymaktır. Bu amaçla, KTÜ Kanuni Kampüsü Fakülteler bölgesindeki yapılar ile Kalkınma Mahallesi'ndeki seçili alanda bulunan yapıların kapladıkları alanlar, yaklaşık büyüklükleri üzerinden CAD ortamında hesaplanmıştır. KTÜ Kanuni Kampüsü alanındaki yapılı alanlar toplamı, Kalkınma Mahallesi alanındaki yapılı alanlar toplamının yaklaşık \%80'ini kaplamaktadır. Bu oranın görsel olarak anlaşılması amacıyla, KTÜ Kanuni Kampüsü Fakülteler bölgesindeki yapı kütlelerinin yaklaşık büyüklükleri eğime paralel kütle izleri olarak işaretlenmiş ve işaretli büyüklükler, Kalkınma Mahallesi’nde seçili alandaki yapılı alanların üzerlerine yerleştirilmiştir. Böylece iki alan arasında yapı yoğunluğu bakımından oluşan fark görsel olarak ortaya konulmuştur (Şekil 17, Şekil 18).

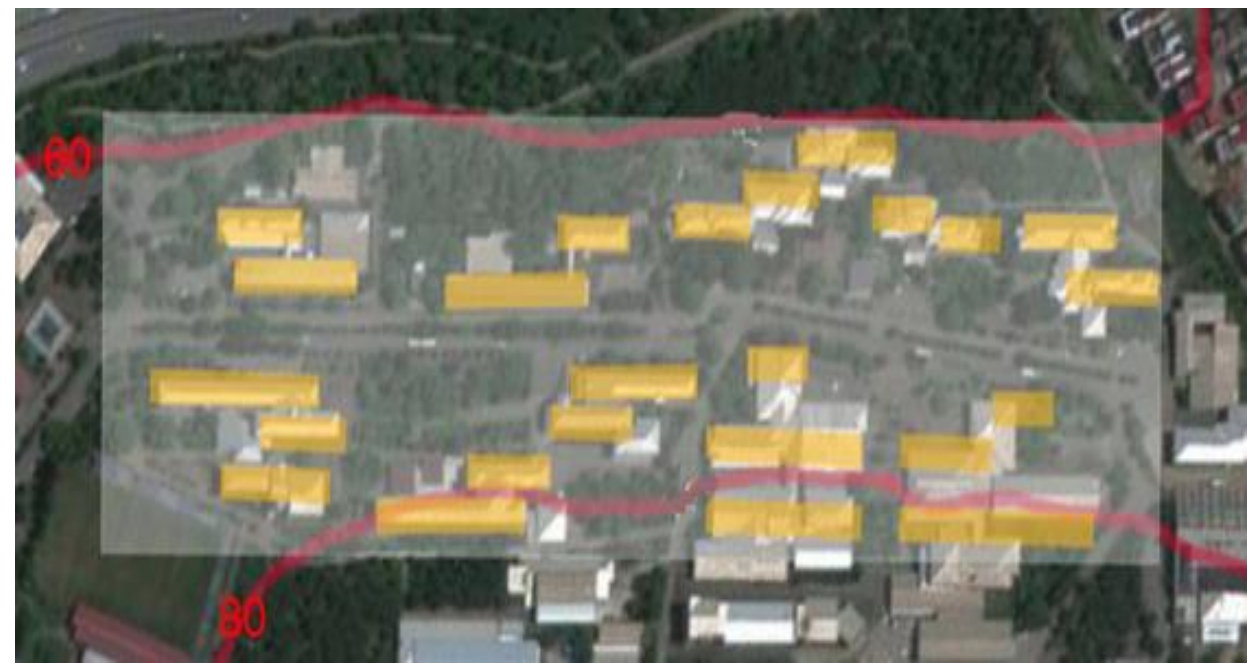

Şekil 16. KTÜ Kanuni Kampüsü Fakülteler Bölgesi. 


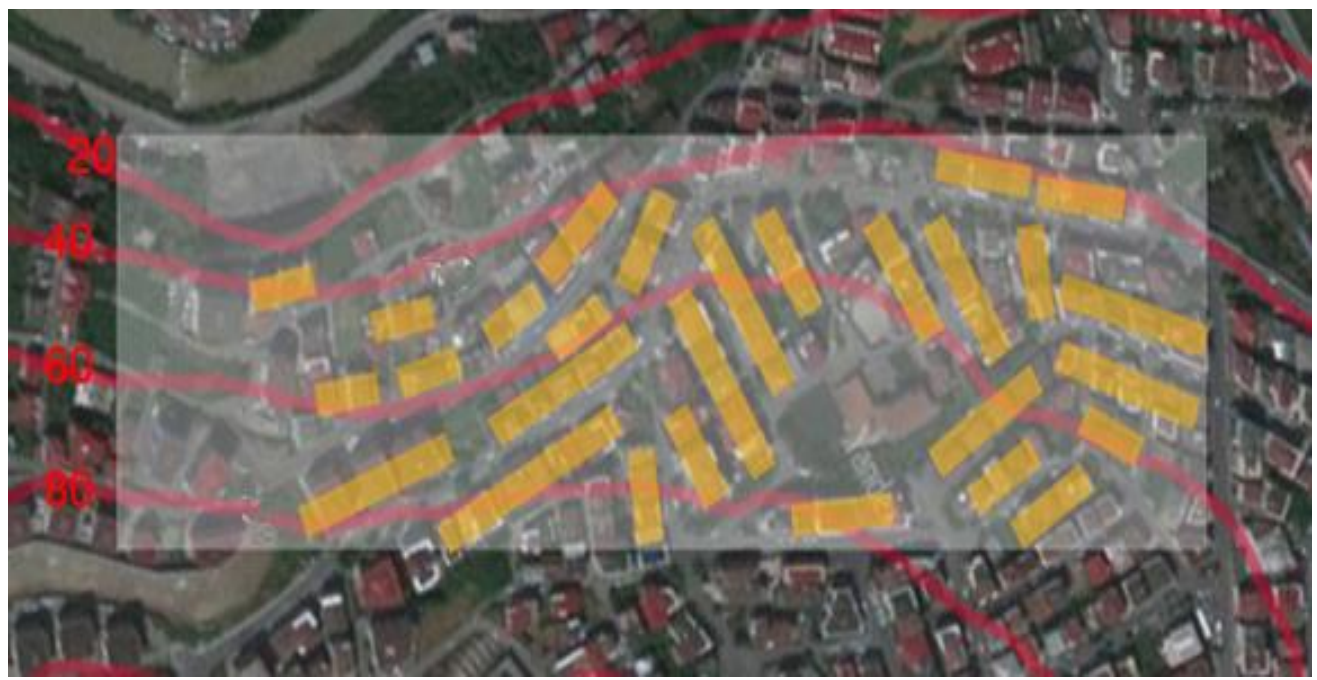

Şekil 17. Kalkınma Mahallesi seçili alan

Bu hesaplama ve görselleştirme ile KTÜ Kanuni Kampüsü Fakülteler bölgesi gibi bir düzenlemenin Kalkınma Mahallesi'nde eş büyüklükte seçilen bir alanda uygulanması halinde, kentsel parçadaki yoğunluğu karşılayıp karşılayamayacağı belirlenmeye çalışılmıştır. Elde edilen sonuç ise Kalkınma Mahallesi alanında, Kampüs yerleşim düzenine benzer yeşil odaklı bir planlamanın uygulanması halinde mevcutta var olan yapı yoğunluğunun \% 80’ini karşılayabileceği, \%20’sinin ise eksik kalacağ 1 şeklinde olmuştur.

Söz konusu yap1 yoğunluğu farkı (\%20); bina kat sayılarının düzenlenmesi/ gerekli yerlerde artırılması, üretilecek konutların metrekarelerinin düzenlenerek sayılarının artırılması veya uygun yerlere uygun büyüklüklerde kütle ekleme yöntemi ile karşılanabilir görünmektedir. Ya da radikal bir yaklaşımla, hızla kuraklaşan kent merkezinin mikro iklimini iyileştirici, yeşilin sürekliliğinin sağlandığı ekolojik ve sürdürülebilir kaliteli çevreler üretilebilmesi adına böylesi bir farkgöz ardı edilebilir ve bu kararın uzun vadede sağlayacağı kazanım daha değerli görülebilir. Sözün özü, bu yaklaşım alan kaybı gibi görülse de yerel iklim değişikliğinin önüne geçilmesi için gerekli ve önemli bir adımdır.

\section{Sonuç ve Öneriler}

Sonuç olarak gelinen bu aşamada, Trabzon kentinde yeşil odaklı yerleşim kurgusunun nasıl gelişebileceği sorusu önem kazanmaktadır. Ilıman iklim kuşağındaki Trabzon'da yerleşim, eğimli yapısından dolayı genelde yamaçlarda gelişmektedir. Yamaçlar ılıman iklime en uygun yerleşim kuşağıdır ve şehir topografik yapısından dolayı yamaçlarda yerleşme bakımından avantajlı durumdadır. Denize dik uzanan havzaların/ vadilerin yamaçları, doğal yeşilin kıyı şeridinden iç kesimlere doğru devam ettiği alanlardır. Bu nedenle Trabzon, yeşilin sürekliliğinin sağlanabilmesi açısından da avantajlı bir coğrafi yapıya sahiptir. Bu bilgiler ve yapılan analizler ışığında Trabzon kenti topografyasına, coğrafi yapısına ve iklimine en uygun yerleşim düzenlerini elde edebilmek üzere yeşil odaklı planlamada dikkat edilmesi gereken temel yerleşim kararları aşağıda sıralanmıştır:

- Yamaçlarda eğime paralel gelişen yol sisteminde yol boyu yerleşme düzeni uygulanmalıdır.

- Bu yerleşim düzeni, sıralı değil şaşırtılmış yeşil alanlarla ve dağınık biçimde; yer yer ayrık nizam, yer yer bitişik nizam bloklar şeklinde yapı düzenleri ile rüzgâr hareketini destekleyen ve yapıların birbirinin güneşini engellemediği yerleşimler olarak kurgulanmalıdır (Şekil 19).

- Yolun iki yanında gelişen yapılı düzeni yapılaşma aksı olarak varsayarsak; eğime paralel yapılaşma aksı sistemleri arasında doğal yeşil dokunun korunduğu yeşil kuşaklar kurgulanarak yeşilin sürekliliği sağlanmalıdır (Şekil 19).

- Yapılaşma aksı içerisindeki kütle hareketleri ve konumlandırmaları ile oluşan boşluklar, yeşilin sürekliliğini yapılaşma aksı içerisine taşıyacak alanlardır. Bu boşluklar ya da açık alanlar KTÜ Kanuni Kampüsü alanındaki gibi yeşille birlikte kurgulanarak yapılaşma alanında yeşilin sürekliliği sağlanmalıdır. $\mathrm{Bu}$ alanlar; ağaçlık alan, yeşille kurgulanan ortak kullanım alanı (avlu, meydancık, sosyalleşme alanı) ya da yeşille kurgulanan otopark alanları olarak düzenlenebilirler (Şekil 13-19).

- Yola yakın konumlanan yapıların yol cepheleri ile araç ve yaya yollarının sert yüzey etkilerinin sıra ağaçlar düzenlenerek giderilmesi sağlanmalıdır. Bu düzenleme yine yeşilin görsel ve fiziksel devamlılığını sağlamaktadır (Şekil 19). 


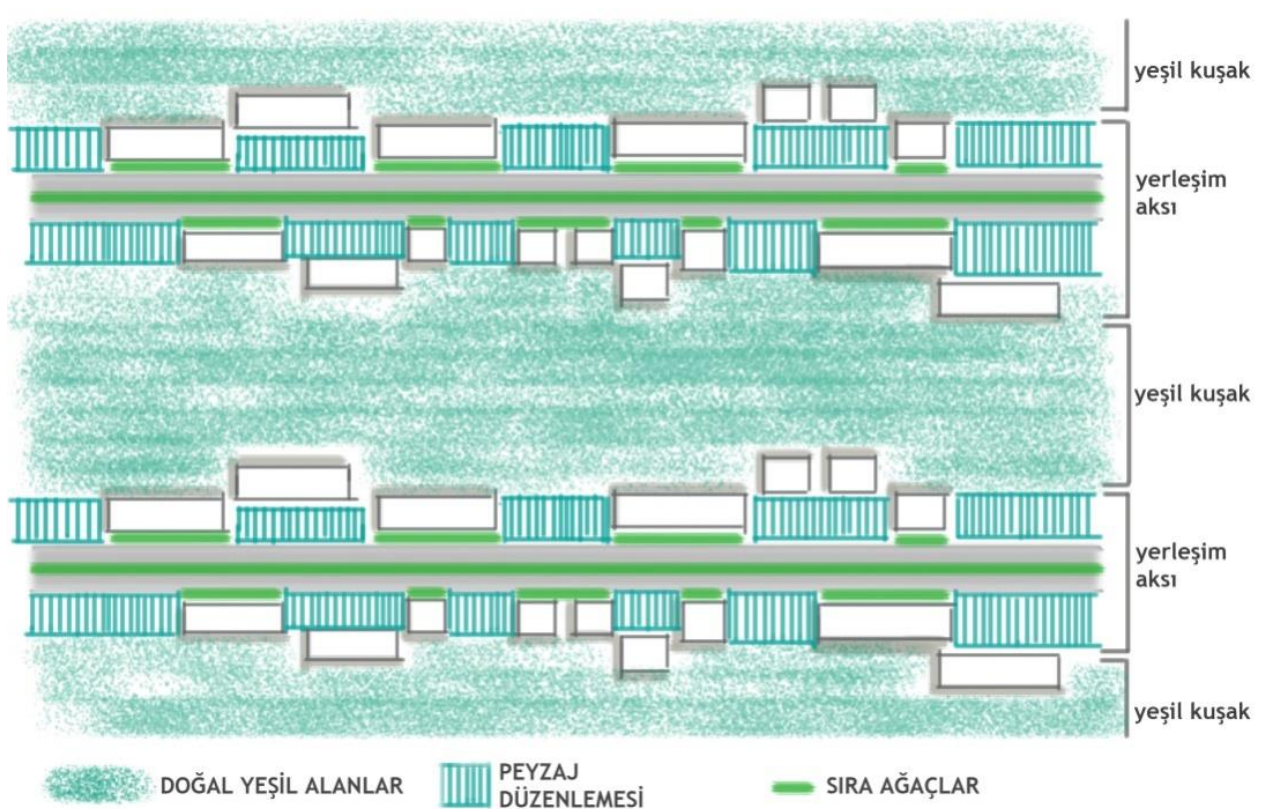

Şekil 18. Trabzon için yeşil odaklı yerleşim düzeni (Çizim: Elif Öztürk).

Trabzon Türkiye'nin en yeşil şehirlerinden biri olmasına karşın gelinen nokta itibari ile ne yazık ki kent içi yeşil bakımından oldukça zayıf kalmıştır. Şehrin doğal yapısının, yeşil odaklı planlanabilir bir kent olmaya son derece uygun olmasına rağmen kent merkezi bu doğrultuda gelişmemektedir. Şekil 19'da ön görülen düzenlemenin yapılmasında en büyük engel şüphesiz ki mülkiyet haklarıdır. Bu bağlamda yeşil odaklı gelişim ile mülkiyet hakları birlikte ele alınarak kurgulanmalıdır. Bu düzenlemenin mülkiyet hakları ile birlikte düşünülmesi zor olsa dahi uzun vadede kentin geleceği söz konusudur. Bu nedenle, baş gösteren kuraklık tehlikesinin ve mikro iklimdeki değişimin olumsuz etkilerinin giderilmesi; doluluk- boşluk dengesinin korunduğu sürdürülebilir bir kent dokusunun oluşturulması; kentin ciğerleri olan yeşil dokunun korunumu ve sürekliliği ile ekosistemin desteklenmesi; kısaca yaşanabilir kaliteli çevreler üretilmesi için bu düzenleme, son derece önemli ve gereklidir.

\section{Kaynaklar}

1. Aksoy, Y., (2014). Türkiye'de Yeşil Alanlarla İlgili Yasal Düzenlemeler, İstanbul Ticaret Üniversitesi Fen Bilimleri Dergisi, 13(26), 1-20.

2. Aru, A. K., (1998). Türk Kenti, Yem Yayınları, İstanbul

3. Bektaş, C., (2014). Türk Evi, Yem Yayınları, İstanbul

4. Demir, K. ve Çabuk, S., (2010). Türkiye'de Metropoliten Kentlerin Nüfus Gelişimi, Erciyes Sosyal Bilimler Dergisi, 28, 2010/1, 193-215.

5. Karataş, A. ve Kılıç, S., (2017). "Sürdürülebilir kentsel gelişme ve yeşil alanlar”, Siyasal: Journal of Political Sciences, 26(2), 53-78.

6. Kuban, D., (1995). Türk ve İslam Sanatı Üzerine Denemeler, Arkeoloji ve Sanat Yayınları, İstanbul

7. Kuban, D., (2018). Türk Ahşap Konut Mimarisi 17.- 19. Yüzyıllar, Türkiye İş Bankası Kültür Yayınları, İstanbul

8. Madge, P., (2009). Ekolojik Tasarım: Yeni Bir Eleştiri, çev. İ. R. Üstüner, Mimar.ist, 02, 50-58.

9. Munier, N., (2007). Handbook on Urban Sustainability, Springer, The Netherlands

10. Polatoğlu, M., (1971). Karadeniz Teknik Üniversitesi, Mimarlık, 87, 45-50.

11. URL-1(2020). Çevre ve Şehircilik Bakanlığı Türkiye Habitat III Ulusal Raporu, Aralık 2014https://webdosya.csb.gov.tr/db/habitat/editordosya/file/HABITAT_III_ULUSAL_RAPOR_(turkce).p df, (12.07.2020)

12. URL-2 (2013). Report of the World Commission on Environment and Development: OurCommonFuture, WCED, 1987, http://www.un-documents.net/our-common-future.pdf, (25.06.2013)

13. URL-3 (2020). Park Royal Singapur https://i.pinimg.com/originals/4a/ca/3e/4aca3ed63cf42d289eedb52674eaefbb.jpg, (10.08.2020)

14. URL-4 (2020). Düsseldorf ofis https://www.globalconstructionreview.com/news/duesseldorf-office-clad-europes-largest-green-faca/, (10.08.2020) 
15. URL-5 (2020). https://www.archdaily.com/catalog/us/products/12673/green-facadesjakob/119662? ad_source=neufert\&ad_medium=gallery\&ad_name=open-gallery, (10.08.2020)

16. URL-6 (2020). Çevre ve Şehircilik Bakanlığı Mekansal Planlar Yapım Yönetmeliği Ek 2 Tablosu, Haziran 2014, https://webdosya.csb.gov.tr/db/mpgm/icerikler/ek-2-tablo-17-mayis-20180214143000.pdf, $(10.08 .2020)$

17. URL-7 (2020). Atatürk Köşkü Ormanı Değerlendirme Raporu https://www.ktu.edu.tr/dosyalar/ormanmuhendisligi_0e50b.pdf, (15.07.2020)

18. URL-8 (2020). https://www.mgm.gov.tr/veridegerlendirme/kuraklik-analizi.aspx, (19.07.2020)

19. URL-9 (2020). http://www.eskiturkiye.net/1977/trabzon-eski-liman, (28.07.2020)

20. URL-10 (2020). Trabzon'da Kuraklık Tehlikesi, https://www.kuzeyekspres.com.tr/trabzonda-kurakliktehlikesi-62273h.htm, (15.07.2020)

21. URL-11(2013). What is Sustainable Architecture, http://www.eslarp.uiuc.edu/arch/ARCH371-F99/groups/k/susarch.html, (30.05.2013)

22. Usta, V., (1999). Anabasis'ten Atatürk'e Seyahatnamelerde Trabzon, Serander Yayınları, Trabzon 